\title{
THE GEBER OF LAM 3 IN LIGHT OF TWO-TIME PERSPECTIVE AND TWO LITERARY CONVENTIONS
}

\section{EL GEBER DE LAM 3 A LA LUZ DE LA PERSPECTIVA DE DOS TIEMPOS Y DOS CONVENCIONES LITERARIAS}

\author{
DARIUSZ IWANSKI \\ Nicolaus Copernicus University
}

\begin{abstract}
Lam 3 has probably received the most attention from scholars studying the Book of Lamentations. One of the most challenging questions concerning this chapter is still the figure of the geber - the main protagonist. There is a cacophony of ideas and interpretations offered in this regard. The current paper is an attempt to simplify the effort of comprehending the figure of the geber offering a new time perspective and reading it through the lenses of two conventions: voice and anonymity. They seem to be sufficient for determining the role of the geber in the poem and possible rhetorical strategy the author employed here. The paper will also give a survey of the most crucial aspects of the scholarly debate relevant for the study.
\end{abstract}

Keywords: Lam 3, the geber, time perspective, literary conventions, voice, anonymity, Everyman. 


\section{RESUMEN}

Lm 3 ha recibido probablemente la mayor atención de los estudiosos del Libro de las Lamentaciones. Una de las preguntas más desafiantes de este capítulo sigue siendo la figura del geber, el protagonista principal. Hay una cacofonía de ideas e interpretaciones que se ofrecen al respecto. El presente artículo es un intento de simplificar el esfuerzo de comprender la figura del geber ofreciendo una nueva perspectiva temporal y leyéndola a través de las lentes de dos convenciones: la voz y el anonimato. Parecen ser suficientes para determinar el papel del geber en el poema y la posible estrategia retórica que el autor empleó. El documento también dará una visión de los aspectos más cruciales del debate académico relevante para el estudio.

Palabras clave: Lam 3, el geber, perspectiva temporal, convenciones literarias, voz, anonimato, hombre común.

The Book of Lamentations continues to puzzle commentators. Its literary structure and composition, a mysterious cast, the question of authorship, gruesome metaphors and violent imagery often stigmatizing women are but some of many issues that stir up a great deal of controversy. Nonetheless, one can note a renaissance of interest in the Book among contemporary scholars ${ }^{1}$. As far as the studies of particular chapters are concerned, Lam 3 seems the most examined ${ }^{2}$. However, there is still a list of issues always debated, and the discussion seems far from ended. Among them, the divergence of opinions and interpretations concerning the figure of the geber is especially impressive and overwhelming at the same time. The current paper is an attempt to simplify the effort of interpreting the dynamics of the geber in the poem and unravel possible rhetorical strategy present here. For doing so, we will offer a new time perspective in looking at the geber's lengthy discourse. Then we are going to see the protagonist through the lenses of two literary conventions present in the chapter - voice, and anonymity ${ }^{3}$.

1 Within the last three decades, studies on Lamentations have flourished and showed signs of transition. More than ten years ago, Adele Berlin, "On Writing a Commentary on Lamentations", en Lamentations in Ancient and Contemporary Cultural Contexts, ed. Nancy C. Lee, Carleen Mandolfo (Society of Biblical Literature Symposium Series 43; Atlanta: Society of Biblical Literature, 2008), 5, noted that generally speaking the research shifted from analyzing specific problems to a more global treatment of various aspects of this literary classic.

2 Miriam J. Bier, 'Perhaps there is Hope': Reading Lamentations as a Polyphony of Pain, Penitence, and Protest (The Library of Hebrew Bible/Old Testament Studies 603; London-New York: Bloomsbury T\&T Clark, 2016), 105.

3 Awareness of the grid of conventions applied in Lamentations, and Lam 3 in particular, seems essential for the reading of this work of art. Robert Alter, The Art of Biblical Narrative (New York: 


\section{THE PROTAGONIST IN THE CONTEXT}

Lam 3 starts right off with a self-presentation in first person singular: "I am the man (haggeber) who saw affliction" (Lam 3:1a). This mysterious selfpresentation leaves much room for guessing and is far from conclusive. It breaks the pattern known from the first two chapters, which started with 'êkäh (alas) and seems to introduce a new kind of protagonist as well as a new time perspective.

\section{A STRONG-WEAK MAN}

The first line of Lam 3 opens with 'ánî (I) which seems to set a very personal tone for the whole address. The term geber points toward a male figure - not just a human being. In the Book of Lamentations, it occurs only in this chapter $(3: 1,27,35,39)^{4}$. One may argue that since it is only once directly referred to the protagonist himself, we should not attach any importance to it. However, what matters is the moment he picks to speak of himself as geber - it is his initial selfintroduction. What comes first, matters most. It stays with the reader and should be crucial for the whole discourse. The reader will bear this image in mind throughout the poem.

The term concerned comes from the Hebrew root $g b r$, meaning be strong, have strength, be mighty, prevail over. So, it conveys the idea of physical strength and power (e.g., Lam 1:16) ${ }^{5}$. H. Kosmala says that the geber is less than gibbor warrior what is indicated by the fact that the first one is not an intensive form. The latter is intensive because the middle letter (bet) there is doubled ${ }^{6}$. If this doubling is enough of a criterion for making a word intensive, then we should not overlook the fact that in our verse a doubling of that same kind occurs. The letter

Basic Books, 1981), 47, stated that thanks to the conventions "we can recognize significant or simply pleasing patterns of repetition, symmetry, contrast; we can discriminate between the verisimilar and the fabulous, pick up directional clues in a narrative work, see what is innovative and what is deliberately traditional at each nexus of the artistic creation". Conventions apply to lyrical texts as well.

4 On the other hand, one must see that this is not the only term referring to "man" in Lam 3. Frederick W. Dobbs-Allsopp, On Biblical Poetry (Oxford-New York: Oxford University Press, 2015), 206, notes that in the sections 3:19-24,25-39 our protagonist "employs a succession of terms for "man" or "human being": geber (vv. 27,35,39), benê-'îs (v.33), and 'ādām (vv. 36,39)". Nevertheless, when the protagonist refers to himself, he never uses any other term but geber or nepeš (man, soul, living being, personality; cf. vv. 17,20,24). The latter further emphasizes the very personal character of his discourse.

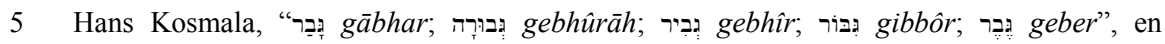
Theological Dictionary of the Old Testament, trad. John T. Willis, ed. Gerhard J. Botterweck y Helmer Ringgren, vol 2, (Grand Rapids, Mi: William B. Eerdmans Publishing Company, 1999), 368.

6 Kosmala, “ גוָבר , gābhar", 373.377. 
gimel gets doubled - as preceded by the definite article (haggeber). So, at least at this early stage, the intensification is already there, or at least is alluded to.

$B D B$ Dictionary does not seem to share Kosmala's reservation toward seeing in geber a warrior-like figure. The dictionary says that this noun serves to emphasize how he is different from women, children, and all unable to carry weapons. It is that last cluster of people that the geber is supposed to defend ${ }^{7}$. At any rate, it is permissible to see in the figure from Lam 3, a mighty man, a man of strength - not just an ordinary male. Only then a terrible paradox becomes apparent - we have here a mighty man whose strength was once reduced to nothing.

Finally, we must note that there is a definite article proceeding the term geber. It has "a demonstrative function: "this strong man"". Moreover, it may be a subtle indication that a well-known figure, of whom everyone is aware, is entering the stage. It makes the whole statement sound as if he wanted to say: sapienti sat-you can figure out who I am. It may also be an allusion to an event of which that figure was a part or merely an echo of a motif that everyone was familiar with (e.g., motif of the suffering righteous - Job). It hardly seems an accidental addition, but no data is allowing us to determine with absolute certainty what the reason for it was. We may speculate that it was intentionally chosen to add some dynamics to the figure of the protagonist. Finally, it excludes the possibility of the word geber being a proper name here since proper names do not take definite articles in Hebrew.

In the Psalter, the meaning of geber takes on a more spiritual meaning. It comes to denote man's intimate relationship with God that results in trust and fear of the Lord (e.g., Ps 40:5,9-12). That relationship, however, does not make him immune to suffering. Calamities may fall upon him (88:5[4]; 89:49-52[48-51]), but this becomes another opportunity to call upon God for help (88:2[1]), and finally taste the salvation he grants ${ }^{9}$.

We may conclude then that the term geber is very complex and conveys the idea of man's strength in at least three ways: physical, moral, as well as spiritual. As such, it was an ideal reference for the main protagonist of Lam 3. His initial testimony is nothing but a story about a mighty man made powerless (vv. 1-18),

7 Francis Brown, "בֶּ geber" en Samuel R. Driver, Charles A. Briggs, Charles A. Briggs, The Brown-Driver-Briggs Hebrew and English Lexicon: With an Appendix containing the Biblical Aramaic (Peabody, Mass.: Hendrickson Publishers, 1996), 149-150.

8 Johan Renkema, Lamentations, trad. Brian Doyle (Historical Commentary on the Old Testament; Peeters-Leuven, 1998), 351.

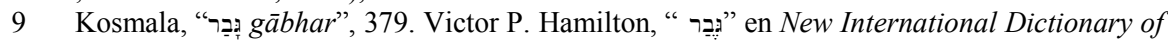
Old Testament Theology \& Exegesis, vol. 1, ed. Willem A. VanGemeren (Grand Rapids: Zondervan Academic, 1997), 816. See other examples of its occurrences in the books of: Job (e.g. 3:3; 4:17; 14:14), Proverbs (e.g. 6:34; 20:24; 28:3), Psalms (e.g. 18:26; 37:23; 89:49), Jeremiah (e.g. 22:30; 30:6; 31:22). 
and that contrast is making the whole story even more intriguing to the reader. It would be in order to dedicate some space to the way the author describes that personal experience. It seems that its placing in time is crucial for the rhetoric of the rest of the chapter.

\section{Time(S) OF AFFLICTION.}

D. Hillers stated that the audience sees the protagonist as "the man who has been through trouble moving into, then out of, near despair to patient faith and penitence, thus becoming a model for the nation. It is the high point of the book, central to it in more than external or formal way"10. R. Perry, similarly to Hillers, claimed "that the man is telling his own story as model to the community of how their story can be seen in such a way that hope for the future is recovered. Just as his suffering has embodied theirs, so the salvation that he has begun to experience can become a foretaste of the future of the community"11. The assumption is that the suffering the geber is alluding to should be interpreted as the current anguish of the nation. As a matter of fact, scholars generally believe that the testimony in vv. 1-18 refers to the ongoing suffering that started with the fall of Jerusalem ${ }^{12}$.

We tentatively propose an alternative way of looking at it, arguing that the discourse of the protagonist assumes two-time dimensions in which it operates. The first of them refers to some unprecedented suffering from the past from which the protagonist eventually got saved. The second one concerns the current miserable time of affliction by which the whole nation - the geber included - is affected. The two are skillfully interwoven to create a dynamic progression of ideas. When realizing this our awareness of a rhetorical strategy employed here rises.

For the first eighteen verses, the geber paints an image of a horrible suffering he once went through. Given the fact that he is addressing the audience of compatriots all of whom suffer, what would be the point in bringing up so much detail if he wanted to refer to the current state of affairs? He instead tends to share

10 Delbert R. Hillers, Lamentations: A New Translation with Introduction and Commentary, second, revised edition (The Anchor Yale Bible 7A; New Haven-London: Yale University Press, 1992), 122.

11 Robin A. Perry, Lamentations (The Two Horizons Old Testament Commentary; Grand Rapids, MI and Cambridge: Wm B. Eerdmans Publishing Co., 2010), 94.

12 E.g., Robin B. Salters, A Critical and Exegetical Commentary on Lamentations (The International Critical Commentary on the Holy Scriptures of the Old and New Testaments; LondonNew York: T\&T Clark International, 2010), 186; Fred W. Dobbs-Allsopp, Lamentations (Interpretation. A Bible Commentary for Teaching and Preaching; Louisville-Kentucky: Westminster John Knox Press, 2002), 109; Dianne Bergant, Lamentations (Abingdon Old Testament Commentaries; Nashville: Abingdon Press, 2003), 82. 
some other tragic experience that happened to him in the past. Even though the situation he is referring to looked hopeless from his point of view, Yahweh finally saved him and so the protagonist knows for a fact that there are no impossible things for him. He is capable of saving the whole nation. It is, in fact, a starting point for the whole message he would want to deliver. He needs something substantial to base that message on. What would be more appropriate than a personally experienced miracle of salvation?

At least three other hints are pointing toward such an approach to the time framework in the text. First, in verse 14, the protagonist says he suffered immensely and was mocked by his nation: "I have become a joke to my people, the butt of their song all day long". It is true that the phrase "my people" is not unanimously accepted by textual critics and commentators. For example, R. Salters favors an alternative reading, namely: "all nations" ". However, MT, as well as LXX, Sym and V have "my people" so there is good reason to keep it as it is ${ }^{14}$. It is hardly possible that the geber elaborates on the current situation since his brokenhearted compatriots would not be in mood for wasting their energy on deriding anyone of their own. Besides, if he were still "a joke to his people", how would he expect to become successful in transmitting any valuable message on to them? How could he perhaps want to call on them for repentance or point the way to the nation (using Hillers' terminology)?

Second, the story ends inconclusively reaching its critical point: pressed to the wall, the geber finally gave up hope (v.18). If hope dies last, then it should be the end of the story. However, all of a sudden, the geber sets a different tone - he is filled with hope (vv. 21,24). That would be hard to account for unless we realize that - without telling us further details - the geber meditates on some incredible act of salvation he experienced. There is again a flashback of the nightmare vividly depicted in vv. 1-18, but now it contrasts with an experience of Yahweh's faithfulness in vv. 19-24. It cannot refer to the current state of affairs since that is still in crying need for a solution. It can only refer back to a personal experience of the geber from the past that in turn will become an excuse for addressing the nation with the message of hope at the current time. That experience will be further, and more directly, alluded to in the final part of the poem (vv. 52-57).

13 Salters, Lamentations, 210.

14 Hillers, Lamentations, 121, notes: "[...] the speaker in 3 is explicitly set apart from "my people" ("ammi, 14) - a point that evidently bothered ancient adherents to the. Collective theory as well, since the reading is changed to "peoples" [...] in the Syriac, some Greek manuscripts, and also in a Sebir having reference to the Masoretic Text, and in some Hebrew manuscripts". Cf. also Bier, 'Perhaps There is Hope', 111. 
Third, the salvation granted brings about a change of attitude and contributes to a higher spiritual maturity of the protagonist. No wonder, then, that what follows now is a calm wisdom discourse (vv. 25-39). Biblical wisdom, as shared by sages, is not a theoretical, but rather, practical knowledge - coming from personal experience and building on the experience of previous generations. This wisdom talk by the geber may seem out of place given the bitterness of the initial testimony unless we assume that it is a product of a previous life-changing experience. $\mathrm{He}$ once saw with his own eyes that there is nothing impossible for Yahweh. Wisdom comes with age and experience. The geber has gained much wisdom due to that experience of personal tragedy and salvation following it.

Fourth, as mentioned above, before the end of the poem, the geber once again returns to his initial testimony. There is a noticeable change of perspective. It is no longer a description of "adversity at the hands of Yahweh"15 , but he rather charges some other human beings with hostile acts against him (vv. 52-54). It is not unusual for the book of Lamentation, though, to picture God and humans interchangeably as ferocious enemies ${ }^{16}$. At any rate, it is best to take vv. 52-54 as a summary of suffering presented in the geber's initial testimony (vv. 1-18). Now, the protagonist gives it its ending providing details about his attitude in the time of misery. Namely, he called upon Yahweh and heard a word of consolation (v. 57) followed by redemption (v. 58$)^{17}$. This pattern may well repeat itself - also on the national scale ${ }^{18}$. It is what the geber is counting on in the present time. Based on his personal experience, he wants to talk his compatriots into the same attitude of almost irrational hope and trust in Yahweh. What follows is his calling on God for salvation on a national level. Even though it is kept in first-person singular at this point, "the speaking "I" has become all-inclusive"19, i.e., embracing the whole troubled nation.

Having set the stage for the operating of the protagonist, we may now pass on to see how creatively the author fashions the protagonist utilizing two conventions: voice and anonymity.

15 Salters, Lamentations, 187.

16 See e.g., 1:5,22;2:22. The most vivid example of God being the enemy is to be found in 2:19,17; see also 1:13-15; 4:11; for humans as enemies see e.g. 1:3,10; 2:16; 4:18-19; 5:8,11-12.

17 Patrick D. Miller, They Cried to the Lord. The Form and Theology of Biblical Prayer (Minneapolis MN: Augsburg Fortress, 1994) 138.

18 It is not unusual for the psalms of lament that the psalmist(s) bring up records of some previously experienced salvation acts - either on a personal or national level (e.g., Ps 22:4-6; 44:2-8; 77:11-20)

19 Dobbs-Allsopp, On Biblical Poetry, 207. 


\section{THE GEBER AS A "VOICE".}

It seems that the scholarly attention to conventions in the Book of Lamentations awoke in the seventies of the last century when W. F. Lanahan published his influential article "The Speaking Voice in the Book of Lamentations" ${ }^{20}$. According to Lanahan behind the scenes, there is an author who introduces actors of the drama who, in turn, speak out for particular groups of Judean survivors. Lanahan names those actors "personae" or "voices". He claimed that the voice(s) is a dominant convention in Lamentations and further explained that the it is "the mask or characterization assumed by the poet as the medium through which he perceives and gives expression to his world"21.

Speaking of the "voices" has now become a standard in the contemporary exegetical debate on Lamentations. Nonetheless, commentators are not unanimous in approaching this phenomenon. For instance, they differ in determining the exact number of voices in the book concerned. For Lanahan they were five ${ }^{22}$, I.W. Provan spoke of three ${ }^{23}$, K.M. Heim argued for at least seven ${ }^{24}$. This plurality of opinions should not intimidate us because, as E. Boase rightly noted, "defining the number of voices within the text is of lesser importance than the recognition of their presence" ${ }^{25}$. Nevertheless, in order to make this paper complete, one needs to address the question of the number of voices in Lam 3.

\section{HOW MANY VOICES?}

The first voice that comes to the fore already in the first verse is the geber. Is he an exclusive soloist in the chapter, or should we expect other voices as well? Scholars opt for one or two voices present there. For instance, D.R. Hillers represents the latter group. He states that "the "I" who speaks at the end (vv. 5266) is not identical with the "I" of the beginning" 26 .

20 William F. Lanahan, "The Speaking Voice in the Book of Lamentations", Journal of Biblical Literature 93,(1974), 41-49.

21 Ibidem, p. 41.

22 More recently this view is supported for example by Erhard S. Gerstenberger, "Elusive Lamentations: What Are They About?", Interpretation 67.2 (2013): 123.

23 Provan, Lamentations, 6-7, 33-34, 57-58, 80-84, 109-110, 123-124.

24 Knut M. Heim, "The Personification of Jerusalem and the Drama of Her Bereavement in Lamentations", en Zion City of Our God, ed. Richard S. Hess y Gordon J. Wenham (Grand Rapids: Wm. B. Eerdmans Publishing Company 1999), 167.

25 Elizabeth Boase, The Fulfilment of Doom? The Dialogic Interaction between the Book of Lamentations and the Pre-Exilic/Early Exilic Prophetic Literature (Library of Hebrew Bible. Old Testament Studies 437; New York: T \& T Clark, 2006), 205.

26 Hillers, Lamentations, 64; see also Gerstenberger, “Elusive Lamentations”, 123-124. 
He further explains that "It may appear inconsistent to make a distinction between the "I" of the end and the "I" of the beginning of the poem, but it seems justified when one recalls that someone reading the poem, or a worshiper hearing it in a service, experiences the poem serially, starting at the beginning, and is not likely to have the end in mind at the start"27. One can hardly deny that the biblical texts have been used for liturgical purposes and that they were divided into parts so that they might be read portion after portion. However, it is somewhat beyond proof that the author had to introduce into the poem another voice just because a reader/worshiper's memory was selective. Thus one should remain skeptical toward Hillers' argumentation.

R. Perry has a somewhat ambivalent opinion about the number of voices here. Even though he opts for only one voice throughout Lam 3, he would not exclude a priori the existence of a second voice in the chapter. Perry is open to a possibility that vv. 42-47 containing a corporate prayer may be uttered by the community in response to the protagonist's call to repentance. If so, he concludes, "then we have a second voice - that of the suffering community" 28 .

F. W. Dobbs-Allsopp, on the contrary, claims that the unknown figure, "a distinctly male voice", who appears already in the very first verse of the chapter is the only voice there ${ }^{29}$. In his opinion neither "generic mixture of the type evidenced in this poem and Lamentations more generally" nor "the modulation in voice between singular and plural", which scholars opting for more than one single voice here saw as factors supporting their view, cannot stand for a proof of a plurality of protagonists ${ }^{30}$.

It seems that Dobbs-Allsopp best responded to the question of the number of voices in Lam 3. For the sake of coherence of the discourse that the chapter contains it is best to think of only one speaker - voice - here. The dynamics of Lam 3 make perfect sense if we envision the same protagonist operating from the beginning till the end. Introducing a new protagonist in the end would be like swapping horses in midstream - i.e. counterproductive for the rhetoric of the whole discourse and the coherence of the poem. It is somewhat necessary that the story used as a point of departure (vv. 1-18), continues and is brought to a positive end (vv. 48-58). Only then one might relate it to the present condition of the audience; and only then it may become a spark of hope for that very audience. It would have a significantly less persuasive power if we had here two protagonists

\footnotetext{
27 Hillers, Lamentations, 131.

28 Perry, Lamentations, 92.

29 Dobbs Allsopp, Lamentations, 105.

30 Dobbs Allsopp, Lamentations,107. See also Salters, Lamentations, 186.
} 
(voices) referring to two different stories of salvation. Such polyphony would be somewhat confusing for the audience - given its condition. So, it is somewhat necessary for the voice to be an exclusive one.

\section{AN INDIVIDUAL OR A COLLECTIVE PERSONALITY?}

Once assumed that there is only one voice in Lam 3, we should further ask how we are supposed to interpret it? Should we regard the geber as an individual or rather a collective subject? ${ }^{31}$. Dobbs-Allsopp notices that scholars opting for an individual here want to see in the geber a person "who is specifically a representative of the larger community or whose experience is paradigmatic of and for the larger community"; those willing to argue for a collective figure here believe that "he is perhaps even another personification of the community"32.

Given the remarkable flexibility that the convention of voice permits, none of the two should be a priori dismissed. If one accepts the voice convention at work here, one also should understand that a single individual may well stand for a collective personality. How then shall we determine the status of the geber as intended by the author? It would be in order to call on some already determined facts. In the poem, we hear just one single voice (as argued above), the voice is distinctively male and anonymous. It is all we can read from the text. As far as the "back end" of the figure is concerned, we may say nothing since we do not have access to that data. Scholars can only speculate about that, and some do in a quite creative way.

Among those opting for the collective interpretation is, for example, A. Berlin, who believes that he is "the personified voice of the exile". Her take on the matter is quite elaborate. She first claims that "the male voice is a counterpart to the female voice of the city in chapter 1. [...] Just as the imagery in chapter 1 was feminine - the widow, the unfaithful wife, the raped woman - so here the imagery seems more masculine, invoking the physical violence against the male body associated with war and exile. [...] Taken together, chapters 1 and 3 give us gendered pictures of a female and male victim - the city, battered and ruined, that remained behind; and the people, entrapped and injured, who were conquered and deported. Second, this male persona is a Job-like figure, crying out in his suffering to a God who refuses to respond [...]. This voice of the nation is, like Job, a literary fiction; but unlike Job, he is not perfect. His sins - the nation's sins - must figure

31 Salters, Lamentations, 185-186, noted that since the beginning of critical scholarship, there were two dominant views concerning the identification of haggeber. He had been viewed as either an individual or collective sufferer.

32 Dobbs-Allsopp, Lamentations, 106. 
in the theodicy. It is not a poem about the suffering of the righteous; it is a poem about the suffering of the guilty" 33 .

There may be several objections raised against this interpretation; but we should see at least three. First, it is debatable how accurate is the claim that the masculinity of the main protagonist seems "invoking the physical violence against the male body associated with war and exile". The Book of Lamentations is rich in imagery of physical violence and brutality, but they are not exclusively attributed to male figures. A good example here might be cannibalism pictured in Lam 2:20 and 4:10 - it is mothers eating their children in the time of famine and siege ${ }^{34}$. Second, to see in the geber a Job-like figure is not wrong, because at first, he may fit into that picture. Nevertheless, what makes Job a suitable protagonist is his being perfect. The whole story may develop hanging on this one feature: Job's perfection. Job is pictured as a perfect yet suffering hero. That is disturbing the common sense of the audience believing in the principle of retribution and, hence, intrigues the reader. "The author is at pains to tell us that Job is perfect; if he were not perfect, the story would have to end after the first trial" ${ }^{\prime 35}$. In other words, his perfection is an essential factor for the story to be carried on. Berlin says explicitly that the geber - is not perfect. So the whole analogy does not hold water. Third, one can hardly claim that the figure of Job represents a more substantial group of mourners - according to Berlin, the geber does. She believes it is the exiles, but there is not even a mention of the exile in the text. Nevertheless, the reference to a biblical wisdom milieu seems very accurate, which we will address later.

On the opposite side, we find for example J. Renkema who does not favor a collective interpretation of the "I" in Lam 3, because it "would simply be a repetition of Lady Jerusalem's claims from the first two songs [...]"36. Instead, he follows exegetes opting for "an individual (literary) interpretation, accepting at the same time that the individual experience of the devout man has meaning, nonetheless, for the entire people [...]"37. His approach is, however, somewhat confusing. He argues that "the figure of the geber is both literary and historical at the same time: literary because he embodies those devout individuals who are tormented by their experiences, questions, and doubts, and who turn to God amid their confusion. In

33 Adele Berlin, Lamentations (The Old Testament Library; Louisville-London: Westminster John Knox Press, 2004) 84-85.

34 Hendrik Bosman, "The Function of (Maternal) Cannibalism in the Book of Lamentations (2:20 \& 4:10)", Scriptura 110.2 (2012), 159-161.

35 Dariusz Iwański, Silenced by Job (Nativity Series I; Menlo Park, 2006) 35; see also Dariusz Iwanski, The Dynamics of Job's Intercession (Analecta Biblica 161; Rome: Pontificio Istituto Biblico, 2006) $72-78.361$

36 Renkema, Lamentations, 344.

37 Ibidem, 344. 
this sense, one can speak of a collective personality: the geber, as he is described in Lam III, represents the people who have been forced to endure all of this affliction"38. So, on the one hand, he dismisses a collective interpretation (p. 344), and on the other, he welcomes it - under certain conditions (p. 351).

Even though Renkema's opinion on the subject seems confusing, he is right when joining exegetes who determine the geber as an individual whose experience is meaningful for the audience. It seems that already in the initial story the main protagonist is sharing, we find hints pointing toward an individual interpretation. First, the self-presentation in verse $1-$ be it an echo of selfpresentation formulas of kings in royal inscriptions from the ancient Near East (an individual king speaking of himself cf. Dobbs-Allsopp, Lamentations, 108) or only the emphasis put on the "I" with which the verse opens up - appears to favor an individual interpretation. In addition, in 3:48, the geber says to weep over "his people's ruin". It would be unnatural to have a group of subjects (supposedly standing behind the figure of the geber) addressing themselves this way. Thus, for the sake of the correct perspective, a disparity of subjects is needed ${ }^{39}$.

Second, we believe that the self-presentation if bearing some royal overtones (see Dobbs-Allsopp) is instead following the pattern of Qohelet's royal fiction. Here is the time to call upon previously mentioned wisdom motifs noted by Berlin. She saw in him a Job-like figure - still coming from the wisdom milieu. That has been addressed as not fully justified; nevertheless, the general intuition is correct, and should be further developed. We propose to look at him as a Qohelet-like figure. Qohelet is first pictured as a king and sage, who, thanks to his royal status, is capable of exploring certain areas of life that an average person would not (cf. Qoh 1:1-2:11). That royal fiction is then abandoned after chapter $2^{40}$. What remains is his status as a wise man, whose teaching is worth giving ear to. No doubt, he is an individual. It would not make sense if he were a corporate identity. We would rather have a single teacher speak to us at one time than a body of teachers commonly sharing their wisdom. A somewhat similar pattern is present

38 Ibidem, 350-351.

39 Claus Westermann, Lamentations. Issues and Interpretation, trad. Charles Muenchow (Minneapolis: Fortress Press, 1994) 69, dismisses a collective interpretation: "because many verses such as v. 27 - only make good sense when they are read as referring to a single individual, and also because the 'I' must on several occasions clearly be distinguished from the people as a whole. The same objection applies to the thesis that some representative of the community is meant by the 'I' of this chapter (Keil, Ewald, Oettli, Ricciotti, Rinaldi)".

40 Thomas Krüger, Qoheleth. A Commentary (Hermeneia - A Critical and Historical Commentary on the Bible; Minneapolis: Fortress Press, 2004) 39-40; Michael V. Fox, A Time to Tear Down \& A Time to Build Up. A Rereading of Ecclesiastes (Grand Rapids: W.B. Eerdmans, 1999) 153. 
in chapter 3. The man is intentionally introduced with some royal overtones (v. 1) and then sounds like a sage sharing words of wisdom (vv. 25-39) ${ }^{41}$.

There is a particular audience whom he addresses. The audience is the devastated nation (previously personified as Lady Zion) driven to the edge. He is hoping for the nation to follow his lead. It would be inconceivable to have a personified nation calling on itself to follow. Fourth, M. Stone rightly noted that the content of Lam 3 may as well support the argument for seeing in the protagonist and individual: "the poet's concern in this third chapter has been deliberately focused more upon personal suffering than upon collective suffering" ${ }^{\prime 2}$.

So, it seems best to look upon the geber as an individual. Given that the convention of voice is at work here, we should address one more problem: is he a real or fictional man hiding behind the cloud?

\section{HISTORICAL OR FICTIONAL?}

Authors who opt for an individual interpretation would see in him either a historical figure (e.g., Jeremiah, king Jehoiachin, king Zedekiah) or simply abstain from precise identifications and instead talk about an unnamed but somewhat characteristic personage (e.g., a devout man, a suffering soldier ${ }^{43}$; "a prominent inhabitant of Jerusalem residing in Zion" $\left.{ }^{44}\right)^{45}$. One especially noticeable way of referring to him is "Everyman" - a term that has resonated in various exegetical studies $^{46}$.

"Everyman" brings to mind a medieval English morality play whose full title is The Summoning of Everyman ${ }^{47}$. The play "portrays a man's struggles, in the face of death, to raise himself to a state of grace so that he may die a holy death, secure in the expectation of everlasting life. [...] The dramatist is careful to present Everyman as a representative, not as an individually well-realized character, so

41 Dobbs-Allsopp, Lamentations, 119-122, calls it "sapiential consolation"; Perry, Lamentations, 102, coins a label for this section: "The Valiant Man Offers General Wise Advice on Suffering".

42 Stone, "Human Suffering", 551. See also: Dobbs-Allsop, Lamentations, 110; Bier, 'Perhaps There is Hope', 109.

43 Lanahan, "The Speaking voice", 41-49.

44 Renkema, Lamentations, 350.

45 For a survey of opinions see Perry, Lamentations, 94-95; Bier, 'Perhaps There is Hope. ' 106.

46 Dobbs-Allsopp, Lamentations, 106-109.

47 Stephen Ney, "Take good heed to the ending: the Medieval Everyman and its modern interpreters", Crux 50.4 (2014) 39-40; Douglas Bruster - Eric Rasmussen (ed.), Everyman and Mankind (London-Oxford-New York-New Delhi-Sydney: Bloomsbury Publishing Plc., 2009) 41.47 .49 
Everyman does not really have a specific past" ${ }^{\text {"48. }}$. As we argued, the geber does have his past, and that is what he builds on (vv. 1-18). It seems that this very nuance should already make one careful about naming our protagonist, "Everyman". However, there is more to it.

Hillers was the first to introduce the label "Everyman" as referred to the protagonist of Lam 3 into the modern studies on the Book of Lamentations ${ }^{49}$. In doing so, he does not seem to make any direct reference to the above mentioned medieval play. The geber's being an Everyman means for Hillers the following: he is "an individual, not a collective figure"; "not a specific historical figure, but rather anyone who has suffered greatly. He is an 'Everyman', a figure who represents what any man may feel when it seems that God is against him. Through this representative sufferer, the poet points the way to the nation, as he shows the man who has been through trouble moving into, then out of, near despair to patient faith and penitence, thus

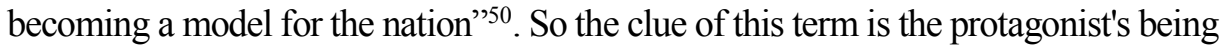
"a representative" of human feelings experienced in the situation when God becomes an enemy and calamities fall upon him. Dobbs-Allsopp follows the designation coined by Hillers, but he slightly twists it. He says that "[...] the man of Lamentations 3 is every bit of Hiller's 'everyman', just a regular guy whose chief distinction - his suffering and the accident of his survival - he shares in common with the other members of the post-destruction community" ${ }^{51}$. Here there is no mention of representing common feelings regarding seeing God as an adversary. Instead, what he seems to emphasize is the geber's being "a regular guy" - touched by calamities shared in common with his leftover compatriots. One may question that "chief distinction" since, if he shares it in common with the rest of the survivors, then what gives him credentials to address the community? If he is just "a regular guy", why would anybody want to listen to him?

Attractive as it may seem, this interpretation is obscuring the picture. To say that the geber is a "typical sufferer" or an "Everyman" sounds like a slogan. Can suffering be measured, stereotyped, or "typical"? Hillers himself shows correct intuition noting that the geber is pictured as "the man who has been through trouble moving into, then out of, near despair to patient faith and penitence, thus becoming a model for the nation". A "typical sufferer" would have never had that

48 Guilliatt A. Lester (ed.), Three Late Medieval Morality Plays: Mankind, Everyman, Mundus et Infants (A New Mermaids Anthology; London-Oxford-New York-New Delhi-Sydney: Bloomsbury Publishing Plc., 1981) xxv-xxvi.

49 Salters, Lamentations, 186, notes that Hillers introduced the term taking his cue from Ewald (324) and Keil (403).

50 Hillers, Lamentations, 122.

51 Dobbs-Allsopp, Lamentations, 109. See also Dobbs-Allsopp, On Biblical Poetry, 207; Renkema, Lamentations, 351. 
strength and will to become a model for anyone. He cannot be either a "regular guy" (as Dobbs-Allsopp wanted) sharing in common with other Judean survivors "his suffering and the accident of his survival". On the contrary, it seems that he must be an extraordinary individual, somebody who had a record of having had gone through unprecedented suffering as we presented it in the first paragraph. That terrible experience he had once to cope with places him above an average sufferer of his time. Only when we consider him an extraordinary individual, can he become a means for the author "to point the way to the nation" - using Hillers' own words. The geber uses the personal experience he dwells on, to help the compatriots move on with their lives as he once did. It is best then to side with scholars abstaining from precise identifications, which ultimately turn into pure guessing. Those identifications are not necessary if one realizes the second convention at work here, namely: anonymity.

Summing up, we should say that we have a voice of a male - a very vocal individual. He is not a corporate personality but a single person with a record of some tremendous suffering followed by a spectacular act of salvation from Yahweh that occurred before the national catastrophe of the time. There is nothing in the text allowing us to determine with precision who that person is. It is useless to ask whether he is a fictional or historical figure. The voice convention makes those questions irrelevant. He is as real as we make him.

\section{ANONYMITY}

One must note right away that anonymity as a convention is not that unusual a phenomenon in the Bible. We may find excellent examples in biblical wisdom literature (see "Woman of Valor" from Proverbs [31,10-31] and Qohelet whose identity is somewhat dimmed) or in Jesus' parables ${ }^{52}$. It would be useless to try to pinpoint the true identity of the man who is reported talking to himself: "You have plenty of grain laid up for many years. Take life easy; eat, drink, and be merry!" (Luke 12:16-20; NIV translation). The anonymous figures are assigned certain roles in epic and lyric texts as well. That should also be true about the protagonist of Lam 3. In other words, he is anonymous, and the author deliberately introduced him as such. Ironically, only if we realize that anonymity, may we assume the role

52 Elizabeth Boase, "Constructing Meaning in the Face of Suffering: Theodicy in Lamentations", Vetus Testamentum 58 (2008), 463, observes: "Wisdom-like material is present in Lam. iii (vv. 25-30; 34-39). The focus of the material is on both the nature of Yahweh and on the proper stance to be taken in the face of suffering". 
assigned to him in the text. However, the problem starts right there, because we may only be guessing what that role might be.

\section{POSSIBLE REASONS FOR CHOOSING THE CONVENTION OF ANONYMITY}

Just as in the case of Job and Qoheleth, the geber is more than a character in a story - he is a "means" for bringing home specific ideas ${ }^{53}$. However, the problem remains: why did the author choose an anonymous figure over an easily recognizable one - as was done, for example, by authors of pseudepigraphical writings? There may be several reasons.

First, it is in line with the first two chapters where the protagonists are anonymous. They are voices: narrator and Lady/Daughter Zion. The first designation (narrator) does not occur in Lam $1-2$, but scholars often use it as a technical term referring to the male figure present there who tries to give an objective picture of the calamities that fell on Judah, the Holy City and the Judeans ${ }^{54}$. The reader never finds out his name. His identity remains mysterious. The figure of the narrator meets the criteria of anonymity. Thus in the case of the geber, we may have a continuation of an earlier adapted convention. In a way, it may help the reader to focus and provides a smooth passage from one chapter to the other.

Second, it may be a groundbreaking effort for introducing a new type of narrator. The main protagonist of Lam 3 is quite different from the previously mentioned figures. Some scholars see him as a counterpart of Lady Zion ${ }^{55}$, but it seems to make much more sense to look at him as resembling the narrator from the first two chapters. His take on the whole story is different from the previous narrator. He must be a different figure then ${ }^{56}$. He never puts on the mask of an impartial reporter as was attempted by the other narrator ${ }^{57}$. Instead, he tries to make it as personal as possible. Right from the start, the geber breaks with the mood of the first two chapters. There we heard the dramatic sigh, "alas!" (Hebr.

53 Michael V. Fox, "Frame-Narrative and Composition in the Book of Qohelet", Hebrew Union College Annual 48 (1977) 94.

54 Charles W. Miller, "Reading Voices: Personification, Dialogism, and the Reader of Lamentations 1", Biblical Interpretation 9.4 (2001), 393.

55 E.g., Berlin, Lamentations, 84. Renkema, Lamentations, 344, speaks of a possibility of "a certain identity between both figures".

56 Perry, Lamentations, 95-96, says: "I tentatively suggest that, when reading in context following Poems 1 and 2, the implied readers will at least entertain the hypothesis that the valiant man is the narrator of the first two poems", but he also admits that "it could be that a third speaker enters the book at this point".

57 Fred W. Dobbs-Allsopp, Weep, O Daughter of Zion: A Study of the City-Lament Genre in the Hebrew Bible (Biblica et Orientalia 44; Rome: Pontifical Biblical Institute, 1993) 33. 
'ekah) as an opening statement (1:1a; $2: 1 \mathrm{a})$. It was hardly neutral in its meaning. On the contrary, it carried quite a vast array of emotions.

Here we have an opening statement by an individual - "I" (Hebr. 'ănî). He signals that he would rather focus on himself, or that he has something personal to share. At first, the reader might find him a megalomaniac. In the face of the disaster, he wants to draw attention to himself? Only further down in his speech, it becomes obvious that he is not a self-centered person. One should rather see there an element of his sophisticated strategy for cheering up his compatriots and boosting their hope for a better future. By his testimony, he wants to gain their trust and build his credentials. The protagonist is consciously working his way to the hearts and minds of his audience. Certain truths are somewhat better conveyed if spoken from behind the cloud of anonymity. One may refer to an example coming from the world of modern writers. Elena Ferrante, one of the most important and successful contemporary Italian writers, firmly refuses to reveal her identity or make public appearances. Elena Ferrante is her pen name. She wants to hide behind this pseudonym. "I discovered that there are difficult truths that are to be written without being anonymous. I have also discovered that there are truths that prefer to have a face that remains in the shadows because the things that are said are so personal that to add blood and flesh to them would mean two things: to give up authenticity of the story or to die of it" ${ }^{\prime \prime}$.

Third, the reason for picking anonymity over revealed identity may have to do with the condition of the audience. The morale of the Judean survivors hit "rock bottom". There was no one to trust or to be trusted. Bringing into the picture someone well recognized with a familiar name and identity, one of the leaders who failed as authorities, would not do any good in this respect. The audience was fed up with authoritative figures, and tended to blame them for the calamities experienced (e.g., priests, prophets, elders cf. $2: 14 ; 4: 13-16)^{59}$. Employing a nonanonymous figure who has not yet made a name for himself would be equally counterproductive. So, the geber is in between. He introduces himself as if everyone should know who he was (see the definite article preceding the noun geber) and yet - even though his story sounds familiar, he is not identified. That leaves room for reading into the text and the character and consequently engages the reader. This way he becomes much more intriguing to the audience. An average reader may have the impression that he or she knows the person speaking from behind the veil due

58 https://www.theguardian.com/books/2015/jun/20/elena-ferrante-author-secret-identitystrega-prize consultado el 23 de Septiembre de 2019

59 Dobbs-Allsopp, Lamentations, 108. 
to some details used in his testimony, but he or she may never be sure since his words do not permit any certainty as far as his identification is concerned.

Fourth, it may be worth mentioning Dobbs-Allsopp's observations regarding the lyrical "I" and a strategy of transitivity, which he finds here. He states that the Book of Lamentations as lyric poetry replaces character by voice and persona, which results in its taking "its familiar pronominal form, prototypically realized as an 'I' addressing a 'You" "60. It is all for the sake of "ritual transitivity" which works the way that the reader "entertains the statements made by the poem's speaker, tries them on, and reexperiences them from the inside, as it were. [...] In this manner, the ritual lyric promotes a transcendence that can begin to envision alternative realities". ${ }^{61} \mathrm{He}$ further argues that the individual "I" of the verses 1-18 by the end of the poem becomes an all-inclusive "I". "Individual auditors are encouraged to try on this voice and what it says because they have been explicitly included in that voice" ${ }^{92}$.

We agree with this approach up to a point. It is undeniable that the anonymous lyrical "I" (voice) would help the reader(s) venting grief which otherwise might be unbearable. It is also most probably true that the author aims to get the reader involved, but that does not need to be achieved by replacing character with an anonymous voice. Most biblical stories, even though not employing anonymous voices, tend to be engaging for the reader. Finally, we disagree with the implication that the lyrical "I" here be read as a "communal voice" becoming a reflection of a common experience. Dobbs-Allsop states: "The 'man's' experience, his suffering as well as his hopes and longings are our experience, that is, the experience of the broader community: his voice is our/communal voice" ${ }^{63}$. If that was the case, what would be the point in that for the reader? Would that bring the audience any comfort? Would that serve just the mere satisfaction that they all suffered equally? One must remain skeptical about such approach. Instead, the author of the poem insists on the geber's individuality and his credentials enabling him to address the audience. They are born out of a very personal experience which occurred before the current national tragedy - as we argued in the first paragraph. Turning to the wisdom instruction he enlarges the picture, showing at the same time his maturity gained by the previously mentioned experience. Now, in the time of national turmoil he has a lot to offer, so he calls upon his audience to act, namely repent and turn to Yahweh for help. Sure enough his personal (individual) testimony of previously experienced

\footnotetext{
60 Ibidem, 13.

61 Dobbs-Allsopp, On Biblical Poetry, 206.

62 Ibidem, 207.

63 Ibidem, 207.
} 
salvation is offered. Moreover, only with that in mind, considering what he and the rest of his audience are going through, he may identify himself with the rest of the nation begging Yahweh for salvation - in first-person singular (vv. 59-66).

Summing up the observations concerning the convention of anonymity employed in Lam 3 we may say that there is no value in trying to establish the identity of the geber because actually it is beyond the purpose of the author. His being an efficient means for the poem does not depend on the reader's getting to know his true self. It is the very logic behind the use of the convention of anonymity. The author creates him as an anonymous figure whom he entrusted with a theological task which otherwise would be challenging. The convention of anonymity is intriguing and engaging at the same time. It helps to address significant problems of the post-destruction community without unnecessary pathos, and avoids hollow advice. It also extends the array of people who might give ear to the testimony of the geber. Familiar to many, yet never adequately identified, intriguing for his unprecedented experience of suffering and salvation, speaking from the heart and not from books, he may sound credible to the biggest skeptics.

\section{SUMMARY}

Fully aware of the multiplicity of opinions and approaches regarding the main protagonist of Lam 3, we attempted to offer one more way looking upon him. First we examined might be understood for the word geber with which he introduces himself (v.1). The term geber conveys the idea of a strong male figure, and his strength has as much physical and moral sense as a spiritual one. The author draws a picture of a man who once strong, was broken by unexpected and terrible suffering. That contrast is crucial for the whole discourse. Then we focused on that discourse which appears multilayered. We argued that it operates in two time dimensions. In one it takes on the form of a flashback referring to some past experience of personal tragedy and salvation from Yahweh that came when hope had died. Then it also touches upon the current national catastrophe that is affecting the Judean survivors - the geber included. The protagonist dwells on that experience in order to bring home his message of hope for the nation. Having once gone through a horrible time of turmoil and having lived some spectacular salvation, he becomes much more credible in addressing the suffering of the nation at the current time. This experience from the past gave him credentials to speak authoritatively - as opposed to the narrator from the two previous chapters who could not. That is an asset not everyone can bring to the table at the time of the disaster on a national scale. 
Having proposed a new time perspective, we went on to examine two crucial conventions that the author used to fashion the figure of the protagonist, namely voice and anonymity. First we dealt with the voice convention. We argued that he was an "exclusive soloist", a male figure, rather individual than corporate personality. He is not just an "Everyman" (as Hillers) or "a regular guy" (as Dobbs-Allsopp), but an extraordinary man who knows the bitterness of suffering and the excitement of salvation. Finally we saw that it was counterproductive to determine whether we should regard him as a fictional or historical figure. The latter does not seem to concern the author.

The author introduces a very individual "voice" - indeed a very talkative figure. Seeing the figure in the voice convention, we should attempt to find out who stands behind this figure - i.e,. on whose behalf does the geber speak. That proved impossible to determine. The fact that the author emphasizes the protagonist's individuality may be an indication that it expresses a single approach amid a small minority of the Judean survivors. That must remain hypothetical, though. However, one can safely assume that the "voice" convention in Lam 3 serves to - nomen omen - give voice to a positive, alternative thinking.

The second convention examined above was anonymity. Nothing in the text legitimizes claims about the so-called "true identity" of the geber. Asking about the identity of the geber betrays lack of understanding and appreciation for the convention of anonymity at work here. All the efforts to the contrary were unproductive and missed the point. The reasons for its use may be different (as outlined above) but it seems undeniable that we should not be so much interested in discovering the identity of the protagonist as of his role in the drama. Anonymity is attractive and intriguing. The figure seems familiar and yet he escapes our ability to read him like a book. The geber is anonymous and for the sake of the drama his identity - whether historical or fictional - should remain in the shadows. The anonymity of the protagonist in Lam 3 is something carefully crafted by the author. The geber is a skillfully fashioned as an anonymous figure compelled to defend matters of utmost importance.

The two conventions help the author to create a very dynamic protagonist. They also contribute significantly to creating a convincing literary environment within which a mysterious figure can operate and become a means for articulating a message of hope. 


\section{REFERENCES}

Alter, Robert. The Art of Biblical Narrative. New York: Basic Books, 1981.

Bergant, Dianne. Lamentations. Abingdon Old Testament Commentaries; Nashville: Abdngdon Press, 2003.

Berlin, Adele. Lamentations. The Old Testament Library; Louisville-London: Westminster John Knox Press, 2004.

Berlin, Adele. "On Writing a Commentary on Lamentations". En Lamentations in Ancient andContemporary Cultural Contexts, editado por Nancy C. Lee, Carleen Mandolfo, 3-11. Atlanta: Society of Biblical Literature, 2008.

Bier, Miriam J. 'Perhaps there is Hope': Reading Lamentations as a Polyphony of Pain, Penitence, and Protest. The Library of Hebrew Bible/Old Testament Studies 603; London-New York: Bloomsbury T\&T Clark, 2016.

Boase, Elizabeth. The Fulfilment of Doom? The Dialogic Interaction between the Book of Lamentations and the Pre-Exilic/Early Exilic Prophetic Literature. Library of Hebrew Bible. Old Testament Studies 437; New York: T \& T Clark, 2006.

Boase, Elizabeth. "Constructing Meaning in the Face of Suffering: Theodicy in Lamentations", Vetus Testamentum 58 (2008), 449-468.

Brown, Francis, Driver Samuel R., Briggs Charles A., The Brown-Driver-Briggs Hebrew and English Lexicon: With an Appendix containing the Biblical Aramaic (Peabody, Mass.: Hendrickson Publishers, 1996).

Bruster, Douglas y Rasmussen, Eric (ed.), Everyman and Mankind. LondonOxford-New York- New Delhi-Sydney: Bloomsbury Publishing Plc., 2009.

Bosman, Hendrik. "The Function of (Maternal) Cannibalism in the Book of Lamentations (2:20 \& 4:10)", Scriptura 110.2 (2012), 152-165.

Dobbs-Allsopp, Fred W. Weep, O Daughter of Zion: A Study of the City-Lament Genre in the Hebrew Bible. Biblica et Orientalia 44; Rome: Pontifical Biblical Institute, 1993.

Dobbs-Allsopp, Fred W. Lamentations. Interpretation. A Bible Commentary for Teaching and Preaching; Louisville-Kentucky: Westminster John Knox Press, 2002.

Dobbs-Allsopp, Frederick W. On Biblical Poetry. Oxford-New York: Oxford University Press, 2015.

Fox, Michael V. "Frame-Narrative and Composition in the Book of Qohelet", Hebrew Union College Annual 48 (1977) 83-106.

Fox, Michael V. A Time to Tear Down \& A Time to Build Up. A Rereading of Ecclesiastes. Grand Rapids: W.B. Eerdmans, 1999.

Gerstenberger, Erhard S. "Elusive Lamentations: What Are They About?", Interpretation 67.2 (2013), 121-132. 
Hamilton, Victor P. "בֶּר:. En New International Dictionary of Old Testament Theology \& Exegesis, vol. 1, editado por Willem A. VanGemeren, 816-817. Grand Rapids: Zondervan Academic, 1997.

Heim, Knut M. "The Personification of Jerusalem and the Drama of Her Bereavement in Lamentations". En Zion City of Our God, editado por Richard S. Hess y Gordon J. Wenham, 129-169. Grand Rapids: Wm. B. Eerdmans Publishing Company, 1999.

Hillers, Delbert R. Lamentations: A New Translation with Introduction and Commentary, second, revised edition. The Anchor Yale Bible 7A; New HavenLondon: Yale University Press, 1992.

Iwański, Dariusz. Silenced by Job. Nativity Series I; Menlo Park, 2006.

Iwanski, Dariusz. The Dynamics of Job's Intercession. Analecta Biblica 161; Rome: Pontificio Istituto Biblico, 2006.

Johnson, Bö. "Form and Message in Lamentations", Zeitschrift für die alttestamentliche Wissenschaft 97.1 (1985) 58-73.

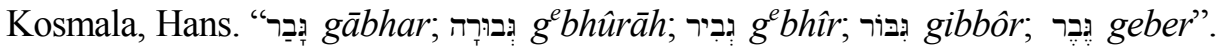
En Theological Dictionary of the Old Testament. Traducido por John T. Willis, vol 2, editado por Gerhard J. Botterweck y Helmer Ringgren, 367-382. Grand Rapids, Mi: William B. Eerdmans Publishing Company, 1999.

Krüger, Thomas. Qoheleth. A Commentary. Hermeneia - A Critical and Historical Commentary on the Bible; Minneapolis: Fortress Press, 2004.

Lanahan, William F. "The Speaking Voice in the Book of Lamentations", Journal of Biblical Literature 93 (1974), 41-49.

Lester, Guilliatt A. (ed.), Three Late Medieval Morality Plays: Mankind, Everyman, Mundus et Infants. A New Mermaids Anthology; London-Oxford-New YorkNew Delhi-Sydney: Bloomsbury Publishing Plc., 1981.

Miller, Charles W., "Reading Voices: Personification, Dialogism, and the Reader of Lamentations 1", Biblical Interpretation 9.4 (2001), 393-408.

Miller, Patrick D. They Cried to the Lord. The Form and Theology of Biblical Prayer. Minneapolis MN: Augsburg Fortress, 1994.

Ney, Stephen. "Take good heed to the ending: the Medieval Everyman and its modern interpreters", Crux 50.4 (2014), 39-42.

Perry, Robin A. Lamentations. The Two Horizons Old Testament Commentary; Grand Rapids, MI and Cambridge: Wm B. Eerdmans Publishing Co., 2010.

Renkema, Johan. Lamentations. Traducido por Brian Doyle. Historical Commentary on the Old Testament; Peeters-Leuven, 1998.

Salters, Robin B. A Critical and Exegetical Commentary on Lamentations. The International Critical Commentary on the Holy Scriptures of the Old and New Testaments; London- New York: T\&T Clark International, 2010. 
Stone, Michael S. "Human Suffering in Lamentations", Revue Biblique 90.4 (1983), 534-555.

Westermann, Claus. Lamentations. Issues and Interpretation. Traducido por Charles Muenchow. Minneapolis: Fortress Press, 1994.

https://www.theguardian.com/books/2015/jun/20/elena-ferrante-author-secretidentity-strega-prize consultado el 23 de Septiembre de 2019.

Dariusz Iwanski

Faculty of Theology

Nicolas Copernicus University

ul. Gagarina 37

87-100 Torun (Poland)

https://orcid.org/ 0000-0001-5444-3219 
